\title{
PHENOTYPIC AND GENOTYPING CHARACTERIZATION OF PASTEURELLA MULTOCIDA IN FARM ANIMALS
}

\author{
Tamer I. Bostan ${ }^{a}$, Helmy A. Torky ${ }^{b}$, Ashraf M. Ahmed ${ }^{c}$, Omnia F. Hassan ${ }^{d}$
}

a Animal health research institute, Tanta, Egypt.

b Department of Bacteriology, Mycology \& Immunology, Faculty of Veterinary Medicine, Alexandria University.

c Department of Bacteriology, Mycology \& Immunology, Faculty of Veterinary Medicine, Kafrelsheikh University.

d Bacteriology Research Department,Animal Health Research Institute, Dokki, Egypt

\begin{abstract}
ABESTRACT
Pasteurella multocida which is the common cause of respiratory disease in cattle causing high economic losses. To achieve this objective, this study succeeded in isolating a total of 27 of $P$. multocida isolates from 280 samples (9.6\%). Lung tissues showed the highest percentage of P. multocida isolation (13.1\%), followed by Nasal Swabs (5\%). These isolates were confirmed microscopically to be P. multocida by staining with Gram's and Leishman's stains, then biochemically by traditional test like indole, catalase, oxidase, urease, citrate utilization, sugar fermentation and gelatin liquefaction tests. Also, the results were confirmed using commercial test API 20E and PCR. For common gene and capsular serotyping of P. multocida by using multiplex capsular PCR typing system, a total of 9 representative isolates were tested and 5 isolates were positive for common gene of $P$. multocida and positive for capsular type E. Positive P. multocida isolates were tested for presence of
\end{abstract}


virulence factors by multiplex PCR for virulence genotyping which represented by virulence genes (TbpA, nanH, ompH and ptfA) which revealed $100 \%$ percentages of Tbpa and nanH in lung tissues and nasal swabs in cattle and buffaloes isolates, the presence of ptfA gene in high percentages in lung tissues in buffalo more than in nasal swabs.

Keywords: Pasteurella multocida, Phenotypic, Genotyping, Farm animals.

\section{INTRODUCTION}

P. multocida is named in honour of Louis Pasteur who in classic experiment in the early 1880 s attenuated the agent and thus produced the first deliberately developed vaccine (Rimler and Glison, 1997). It is one of the most fascinating gram-negative bacteria and is a commensal of the upper respiratory tract of many animal species. However, under predisposing circumstances the organism is the etiological agent of a wide range of economically important diseases, including fowl cholera in poultry, haemorrhagic septicaemia in cattle and buffalo, atrophic rhinitis in swine and snuffles in rabbits. The organism is also known to be the causative agent of Pasteurellosis in American bison, yak, deer, elephants, camels, horses, elk and other wild animals (De Alwis, 1996). The pathogen consists of five capsular type $\mathrm{A}, \mathrm{B}, \mathrm{D}, \mathrm{E}$, and $\mathrm{F}$ and there is relationship exist between the capsular type and disease predilection (Boyce and Adler, 2001).

The bacterial outer membrane forms the interface between host and gram negative bacterial pathogen. The constituents of the membrane are proteins, lipopolysaccharides and polysaccharides. Further proteins have been reported to be immunologically dominant (Mukkur, 1978) and Kafrelsheikh Vet. Med. J. Vol. 14 No. 1 (2016) 
OMPs can play important pathogenic roles such as expression of virulence factor, adhesions and surface antigens. Also selection of $P$. multocida strains with high OMP production under modified cultural conditions could enhance vaccine potency (Srivastava, 1998).

Phenotyping methods, mainly biotyping and serotyping have been widely used in the taxonomy and epidemiological studies of this species (Mohan et al., 1994). Due to shortfalls associated with phenotypic techniques, genotyping techniques have been used extensively to differentiate epidemiologically significant strains of $P$. multocida (Lainson et al., 2002). RAPD is receiving more attention and has been applied for distinction of strains belonging to same or different species. This method has been used in a variety of bacteria (Dziva et al., 2001; Chaslus-Dancla et al., 1996).

VFs play a key role in disease production by bacterial pathogens (Nanduri et al., 2009). Among others, their functions include competence, adherence, synthesis, and export of capsules; and evasion of host immune responses (Nanduri et al., 2009). In the present study the factors have been detected in P. multocida isolated from the lungs of slaughter cattle. The higher frequency of the factors among isolates from pneumonic lungs suggests the role of these factors in disease occurrence. It was pointed out that virulence gene occurrence in P. multocida has a strong positive association with the outcome of infection with the organism in cattle (Katsuda et al., 2013). On the other hand occurrence of the factors in apparently healthy lungs could possibly indicate early infection or contained infection which couldn't lead to disease. It was previously reported that this facultative anaerobic bacterium is commonly found in clinically healthy calves (Lainson et al, 2013). 


\section{MATERIAL AND METHODS}

\section{Sampling:}

A total of 120 nasal swabs collected from diseased cattle and buffaloes of different sex, age and localities in Gharbia Governorate and a number of 160 lung pieces collected from diseased cattle and buffaloes from abattoirs in Gharbia Governorate.

\section{Methods:}

\subsection{Phenotyping characterization:}

isolation of organisms from the samples according to methods described by Cruickshank et al., (1975) and Quinn et al., (1994).

Identification of $P$. multocida Isolates by biochemical tests according to methods described by Cruickshank et al. (1975) and Mackie and MacCarteny (1996).

Pathogenicity test was done according to Ali (1991).

\subsection{Genotyping characterization of Pasteurella multocida:}

\subsubsection{Capsular serotyping of Pasteurella multocida by Multiplex} Capsular PCR:

It was done according to Townsend et al., (2001).

\subsubsection{Virulence genotyping of Pasteurella multocida by Multiplex PCR:}

It was done for detecting virulence genes (ptfA, nanH, omph and TbpA) according to Ewers et al., (2006). 
Phenotypic And Genotyping Characterization Of ...

Table (1): Primer sequences, and PCR product size for Multiplex capsular PCR:

\begin{tabular}{|c|c|c|c|c|}
\hline serogroup & gene & Name & Sequences & size \\
\hline All & KMT1 & $\begin{array}{l}\text { KMT1T7 } \\
\text { KMT1SP6 }\end{array}$ & $\begin{array}{l}\text { ATCCGCTATTTACCCAGTGG } \\
\text { GCTGTAAACGAACTCGCCAC }\end{array}$ & 460 \\
\hline A & hyaD-hyaC & $\begin{array}{l}\text { CAPA-FWD } \\
\text { CAPA-REV }\end{array}$ & $\begin{array}{l}\text { TGCCAAAATCGCAGTCAG } \\
\text { TTGCCATCATTGTCAGTG }\end{array}$ & 1044 \\
\hline B & $b c b D$ & $\begin{array}{l}\text { CAPB-FWD } \\
\text { CAPB-REV }\end{array}$ & $\begin{array}{l}\text { CATTTATCCAAGCTCCACC } \\
\text { GCCCGAGAGTTTCAATCC }\end{array}$ & 760 \\
\hline $\mathrm{D}$ & $d c b F$ & $\begin{array}{l}\text { CAPD-FWD } \\
\text { CAPD-REV }\end{array}$ & $\begin{array}{l}\text { TTACAAAAGAAAGACTAGGAGCCC } \\
\text { CATCTACCCACTCAACCATATCAG }\end{array}$ & 756 \\
\hline $\mathrm{E}$ & $e c b J$ & $\begin{array}{l}\text { CAPE-FWD } \\
\text { CAPE-REV }\end{array}$ & $\begin{array}{l}\text { TCCGCAGAAAATTATTGACTC } \\
\text { GCTTGCTGCTTGATTTTGTC }\end{array}$ & 511 \\
\hline $\mathrm{F}$ & $f_{c b D}$ & $\begin{array}{l}\text { CAPF-FWD } \\
\text { CAPF-REV }\end{array}$ & $\begin{array}{l}\text { AATCGGAGAACGCAGAAATCAG } \\
\text { TTCCGCCGTCAATTACTCTG }\end{array}$ & 851 \\
\hline
\end{tabular}

Table (2): Primer sequences, and PCR product size for Multiplex virulence PCR:

\begin{tabular}{|c|c|c|c|}
\hline gene & Name & Sequences & size \\
\hline TbpA & $\begin{array}{l}\text { KMT1T7 } \\
\text { KMT1SP6 }\end{array}$ & $\begin{array}{l}\text { TTGGTTGGAAACGGTAAAGC } \\
\text { TAACGTGTACGGAAAAGCCC }\end{array}$ & 728 \\
\hline $\operatorname{nanH}$ & $\begin{array}{l}\text { CAPA-FWD } \\
\text { CAPA-REV }\end{array}$ & $\begin{array}{l}\text { CACTGCCTTATAGCCGTATTCC } \\
\text { AGCACTGTTACCCGAACCC }\end{array}$ & 964 \\
\hline ompH & $\begin{array}{l}\text { CAPB-FWD } \\
\text { CAPB-REV }\end{array}$ & $\begin{array}{l}\text { CGCGTATGAAGGTTTAGGT } \\
\text { TTTAGATTGTGCGTAGTCAAC }\end{array}$ & 438 \\
\hline ptfA & $\begin{array}{l}\text { CAPD-FWD } \\
\text { CAPD-REV }\end{array}$ & $\begin{array}{c}\text { TGTGGAATTCAGCATTTTAGTGTGTC } \\
\text { TCATGAATTCTTATGCGCAAAATCCTGCTGG }\end{array}$ & 488 \\
\hline
\end{tabular}

Kafrelsheikh Vet. Med. J. Vol. 14 No. 1 (2016) 


\section{RESULTS}

Table (3): Number of suspected isolates of P. multocida from nasal swabs and lung tissues:

\begin{tabular}{|c|c|c|c|}
\hline \multirow{2}{*}{ Type of samples } & \multirow{2}{*}{ Number } & \multicolumn{2}{|c|}{$\begin{array}{c}\text { Number of suspected isolates of } P \text {. multocida from } \\
\text { nasal swabs and lung tissus }\end{array}$} \\
\hline & & $+v e$ & $\%$ \\
\hline Nasal swabs & 120 & 6 & $5.0 \%$ \\
\hline Pneumonic lung tissues & 160 & 21 & $13.1 \%$ \\
\hline Total & 280 & 27 & $9.6 \%$ \\
\hline
\end{tabular}

Table (4): Total number of suspected P. multocida from nasal swabs and lung tissues according to animal:

\begin{tabular}{|c|c|c|c|c|}
\hline Type of sample & Animal & $\begin{array}{c}\text { Number of } \\
\text { examined sample }\end{array}$ & $\begin{array}{c}\text { Number of } \\
\text { positive cases }\end{array}$ & $\begin{array}{l}\text { Incidence } \\
\text { percentage }\end{array}$ \\
\hline \multirow{2}{*}{ Nasal swabs (120) } & cattle & 45 & 1 & $2.2 \%$ \\
\hline & buffaloes & 75 & 5 & $6.6 \%$ \\
\hline \multirow{2}{*}{ Lung tissues(160) } & cattle & 50 & 8 & $16 \%$ \\
\hline & buffaloes & 110 & 13 & $11.8 \%$ \\
\hline Total & & 280 & 27 & $9.6 \%$ \\
\hline
\end{tabular}

Identification of pasteurella multocida and capsular serotyping using Multiplex Capsular PCR Typing System:

The Pasteurella multocida multiplex PCR assay based on KMT1T7 and KMT1SP6 primers gives a positive signal by amplicon of approximately 460bp with five Pasteurella multocida isoates and also based on CAPA-FWD, CAPA-REV, CAPB-FWD, CAPB-REV, CAPDFWD, CAPD-REV, CAPE-FWD, CAPE-REV, CAPF-FWD, CAPFREV which give a positive signal by amplicon of approximately $511 \mathrm{bp}$ with five Pasteurella multocida isolates as in Fig. (1). 


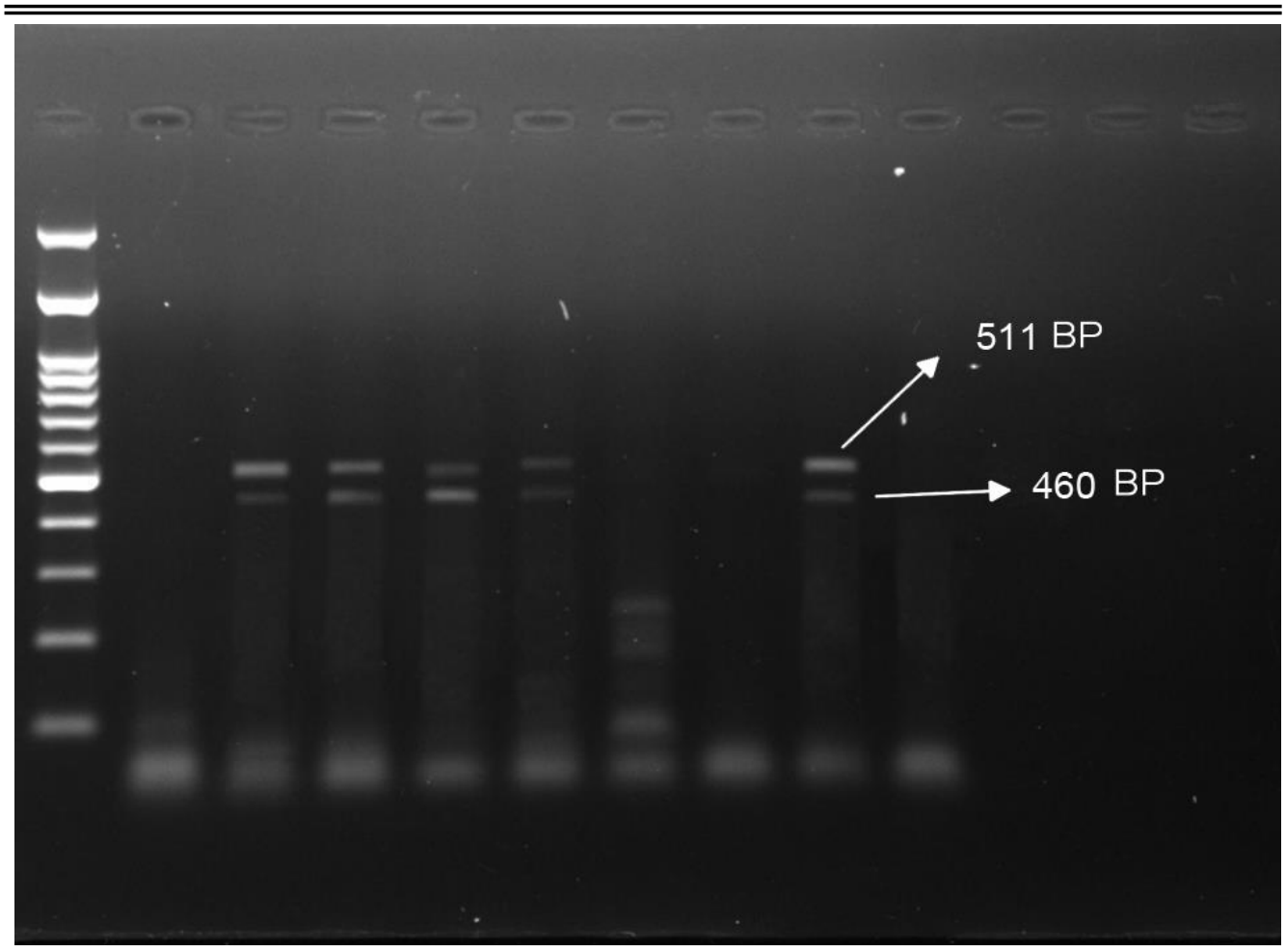

Fig. (1): Agarose gel electrophoresis PCR amplified products of $P$. multocida field isolates. Lane 1 DNA molecular size marker, Lane 3, 4, 5, 6, 9 are multiplex PCR products from Pasteurella multocida isolates, Lane 2, 7, 8, 10 are negative samples.

Identification of pasteurella multocida virulence genes using Multiplex PCR:

The Pasteurella multocida virulence genes based on $\mathrm{OmpH}, \mathrm{NanH}$, TbpA, Fim4 primers which revealed to $\mathrm{OmpH}$, NanH, TbpA and ptfA virulence genes of Pasteurella multocida which give a positive signal of amplicon size of 488 bp for ptfA gene and 964 bp for $\mathrm{NanH}$ gene and 728 bp for TbpA gene. 
Tamer I. Bostan et., al.

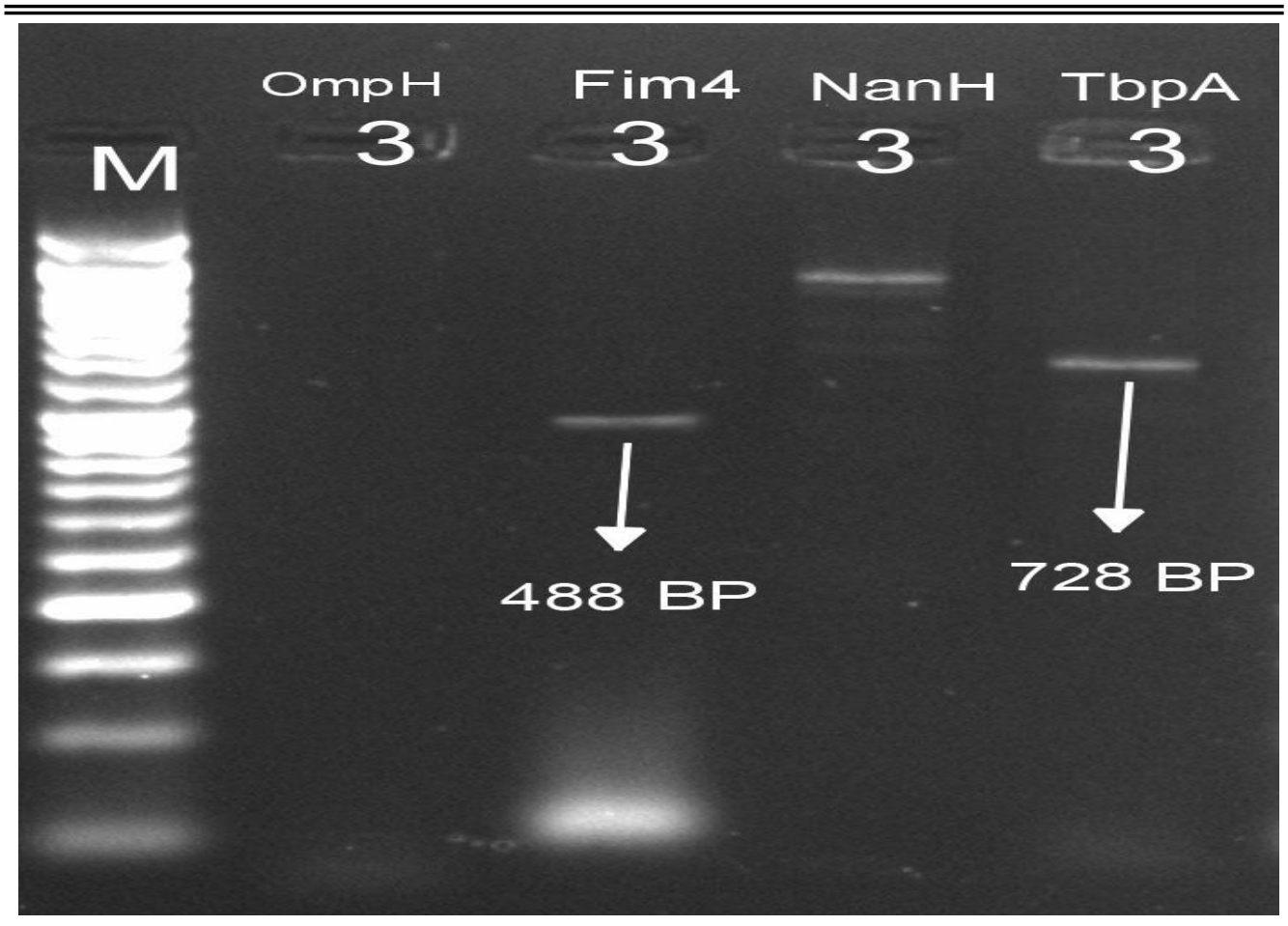

Fig. (2): Agarose gel electrophoresis PCR amplified products of $P$. multocida field isolates. Lane 1 DNA molecular size marker, Lane 2: OmpH gene negative result, Lane 3: Fim4 gene positive result, Lane 4: NanH gene positive result, Lane 5: TbpA gene positive result.

Percent distribution of virulence associated genes in $P$. multocida according to samples type:

\begin{tabular}{|c|c|c|c|c|}
\hline Type of Samples & TbpA Gene & NanH Gene & ptfA Gene & OmpH Gene \\
\hline Swabs & $33.3 \%$ & $33.3 \%$ & $0 \%$ & $0 \%$ \\
\hline Lung tissues & $67.7 \%$ & $67.7 \%$ & $33.3 \%$ & $0 \%$ \\
\hline Total & $100 \%$ & $100 \%$ & $33.3 \%$ & $0 \%$ \\
\hline
\end{tabular}

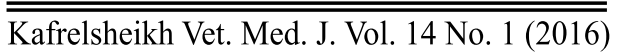




\section{DISCUSSION}

The present study was performed to isolation and identification of P. multocida from suspected cases of pasteurellosis in cattle and buffaloes at Gharbia governorate.

The samples of buffaloes and cattle isolates which showed the presence of bipolar organisms in smears of $P$. multocida are in agreement with (Asma et al., 2011).

The bacterial colonies of $P$. multocida isolates on blood agar were small, non-haemolytic, round, smooth. All the isolates failed to grow on MacConke'y agar. On the Gram staining the isolates were found to be Gram negative coccobacillary rods while on methylene blue stain showed the bipolarity of the bacteria. These results are similar to the findings of (Quinn et al., 1994).

In the present study, 280 samples were examined for presence of pasteurella multocida which revealed 27 positive samples with incidence 9.6\%, and this results are nearly similar to Sedeek and Thabat (2001) isolated Pasteurella multocida with frequency (8.3\%) from infected bovines and Shayegh et al., (2010) with frequency (6.02\%) from cattle and buffaloes and this results are less than results of Naz et al., (2012) reported that Pasteurella multocida was most frequent (80\%) isolated organism from infected lungs.

Although the molecular basis of the pathogenicity and host specificity of $P$. multocida is not well understood, the organism is known to possess a number of virulence factors which have integrated role in pathogenesis (Hunt et al., 2000a and Harper et al., 2006). The present study was thus carried out to study the prevalence of virulence associated

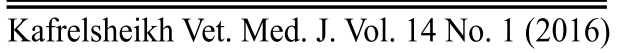


genes in the bovine isolates of $P$. multocida. The prevalence of 4 virulence associated genes which included genes coding for iron acquisition factors (tbpA), adhesion related genes (ptfA, nanH), outer membrane and porin proteins $(\mathrm{ompH})$.

The prevalence of virulence associated genes was found to vary among $P$. multocida isolates recovered from various host species. Significant association between toxA and nanH genes with host origin was also observed. Dermonecrotoxin gene was found to be positively associated with porcine isolates, whereas nanH gene was found to be positively associated with large ruminant isolates, more specifically with cattle isolates, which agrees well with the findings of (Ewers et al., 2006).

The type 4 fimbria (ptfA gene) was described in $33.3 \%$ of the isolates tested in the current study. The gene plays a key role of fixing bacterial pathogens on the surface of the epithelial cells of hosts, a phenomenon which is more common in pneumonic lungs in buffaloes (Ewers et al., 2006).

Presence of adhesins on the bacterial surface is usually linked to virulence as these proteins are known to play a crucial role in facilitating host invasion and colonization (Kline et al., 2009). Studies by (Ewers et al., 2000) and (Tang et al., 2009) have demonstrated that, of the adhesins; fimA, hsf-2, and ptfA are of frequent occurrence among pathogenic isolates of $P$. multocida.

The tbpA and nanH encoding genes presented by $100 \%$ of common occurrence among ruminant $P$. multocida strains and this results are similar to (Ewers et al., 2006; Atashpaz et al., 2009). 


\section{REFERENCES}

- Ali, H.A. (1991): The problem of bacterial respiratory diseases in rabbits. M. V. Sc. in Mousl, Iraqi, Journal of Vet. Sci., 8(2): 271-277.

- Asma, A.; Hassan, T.; Salahuddin, S.; Shahid, N.; Irfan, M.; Sadia, A.; Ambreen, I.; Sadia, G. and Shahid, M. (2011): Characterization of Pasteurella multocida strains isolated from cattle and buffaloes in Karachi, Pakistan. African Journal of Microbiology Research Vol. 5(26) pp. 4673-4677.

- Atashpaz S., Hejazi M.S. and Shaeygh J. (2009): Design of multiplex PCR for virulence typing of Pasteurella multocida strains. Res. Vet. Sci., 87, 355-357.

- Boyce, J.D. and Adler, B. (2001): A capsular Pasteurella multocida B: 2 can stimulate protective immunity against pasteurellosis. Infect. Immun. 69: 1943-1946.

- Chaslus-Dancla, E.; Lesage-Descauses, M.C.; Leroy-Sétrin, S.; Martel, J.L.; Coudert, P. and Lafont, J.P. (1996): Validation of random amplified polymorphic DNA assays by ribotyping as tools for epidemiological surveys of Pasteurella from animals. Vet. Microbiol. 52: $91-102$.

- Cruickshank, R.; Duguid, J.P.; Marimon, B.P. and Swain, R.A.H. (1975): Medical Microbiology, 2nd Edn. Vol.I, Church Hill, Livingstone, Edinburgh.

- De Alwis, M.C.L. (1996): Haemorrhagic septicaemia : Clinical and epidemiologial features of the disease. Int. Workshop on diagnosis and control of H.S. Bali.Indonesia. 
- Dziva, F.; Christensen, H.; Olsen, J.E. and Mohan, K. (2001): RAPD and phenotypic typing of Zimbabwean isolates of Pasteurella multocida. 82: 361-372.

- Ewers, C.; Lübke-Becker, A.; Bethe, A.; Kiebling, S.; Filter, M. and Wieler, L.H. (2006): Virulence genotype of Pasteurella multocida strains isolated from different hosts with various disease status. Vet. Microbiol. 114(3-4): 304-317.

- Harper M, Boyce JD, Adler B (2006): Pasteurella multocida pathogenesis: 125 years after pasteur. FEMS Microbiol. Lett. 265:1-10.

- Hunt ML, Adler B, Townsend KM (2000a): The molecular biology of Pasteurella multocida. Vet Microbiol 72:3-25.

- Katsuda, K., Hoshinoo, K., Ueno, Y., Kohmoto, M., and Mikami, O. (2013): Virulence genes and antimicrobial susceptibility in Pasteurella multocida isolates from calves. Vet. Microbiol. 167, 737741. doi: 10.1016/j.vetmic.2013. 09.029.

- Kline, K. A., Fälker, S., Dahlberg, S., Normark, S., and HenriquesNormark, B. (2009): Bacterial adhesins in host-microbe interaction. Cell Host Microbe5, 580-592. doi: 10.1016/j.chom.2009.05.011.

- Lainson, F.A.; Aitchison, K.D.; Donachie, W. and Thomson, J.R. (2002): Typing of Pasteurella multocida isolated from pigs with and without porcine dermatitis and nephropathy syndrome. J. Clin. Microbiol. 40: 588-593. 
- Lainson, F.A.; Dagleish, M.P.; Fontaine, M.; Bayne, C. and Hodgson, J.C. (2013): Draft genome sequences of strains of Pasteurella multocida isolated from the United Kingdom and the United States. Genome Announc. 1(5): e00773-13.

- Mackie, T. J. and MacCarteny, J. E. (1996): Medical microbiology, $14^{\text {th }}$ Ed. Vol. II, the practice of Medical Microbiology, Churchill Livingstone Edinburgh, London and New York.

- Mohan, K.; Sadza, M.; Madsen, M.; Hill, F.W. and Pawandiwa, A. (1994): Phenotypic characterization of Zimbabwean isolates of Pasteurella multocida. Vet. Microbiol. 38: 351-357.

- Mukkur, T.K.S. (1978): Immunologic and physiologic response in calves inoculated with potassium thiocyanate extract of Pasteurella multocida type A. Am. J. Vet. Res. 39: 1269-73.

- Nanduri, B., Shack, L. A., Burgess, S. C., and Lawrence, M. L. (2009): The transcriptional response of Pasteurella multocida to three classes of antibiotics. BMC Genomics10:S4 doi: 10.1186/1471-216410-S2-S4.

- Naz, S., Hanif, A., Maqbool, A., Ahmed, S., and Muhammand K. (2012): Isolation, characterization and monitoring of antibiotic Resistance in Pasteurella multocida isolates from buffalo (bubalus Bubalis) herds around Lahore. J. Anim. Plant Sci., 22(Sup 3): 242-245.

- Quinn, P.J.; Carter, M.E.; Markey, B.K. and Carter, G.R. (1994): Veterinary Clinical Microbiology, Wolfe Publication, London, U.K., pp: 254-258. 
- Rimler, R.B. and Glisson, J.R. (1997): Fowl cholera. In B.W.Calnek, H.J.; Barnes, C.W.; C.W.Beard; L.R.MacDougald and Y.M.Saif (Eds.). Disease of poultry 10th edn. Pp: 143-159. Ames, Iowa : State University Press.

- Sedeek, S. R. and Thabat, A. M. (2001): Some studies on bacterial causes of pneumonia in cattle in Assuit Governorate. Assuit Vet. Med. J. 45(90): $243-255$.

- Shayegh J, Atashpaz S, Zahraei TS, Hejazi MS (2010): Potential of Pasteurella multocida isolated from healthy diseased cattle and buffaloes in induction of diseases. Bulletin of the Veterinary Institute in Pulawy, 54: 299-304.

- Srivastava, S. K. (1998): Outer membrane protein of Pasteurella multocida serotype B: 2 are immunogenic and antiphagocytic. Indian J. Exp. Biol. 36: 530-532.

- Tang, X., Zhao, Z., Hu, J., Wu, B., Cai, X., He, Q., et al. (2009): Isolation, antimicrobialm resistance, and virulence genes of Pasteurella multocida strains from swine in China.J. Clin. Microbiol. 47, 951-958. doi: 10.1128/JCM.02029-08.

- Townsend, K.M.; Boyce, J.D.; Chung, J.Y.; Frost, A.J. and Adler, B. (2001): Genetic organization of Pasteurella multocida cap loci and development of a multiplex capsular PCR typing system. J. Clin. Microbiol. 39: 924-929. 
التوصيف الظاهري و الور اثي للباستيريلا مالتوسيدا في حيوانات المزارع

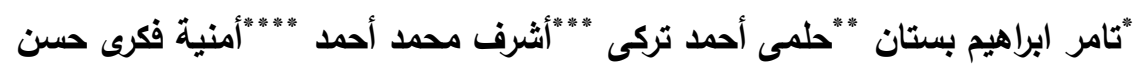
" معهُ بحوث صحة الحيوان , طنطا , الغربية , مصر

" قسم البكتريولوجيا والفطريات والمناعه كلية الطب البيطري- جامعة الأسكندرية , مصر بر " • قسم البكتريولوجيا والفطريات والمناعه كلية الطب البيطري- جامعة كفرالثيخ , مصر •... قسم البكتريولوجيا , معهُ بحوث صحة الحيوان , دقي , جيزة , مصر

ميكروب الباستيريلا مالتوسيدا هو المسبب الثائع لأمراض الجهاز التتفسي بالماشية التي تسبب خسائر اقتصادية عالية والعزل الأولي للميكروب وإجراء الاختبارات الكيميائية عليه وعزله باستخدام تقنية البى سى ار وعزل جينات الضراوة من الميكروب باستخدام تقنية البى سى ار ـ ولتحقيق هذه الأهداف تم عزل 27 عترة للباستيريلا مالتوسيدا من 280 عينة حقلية نم تجميعها بنسبة (9.6\%). ومن نتائج العزل

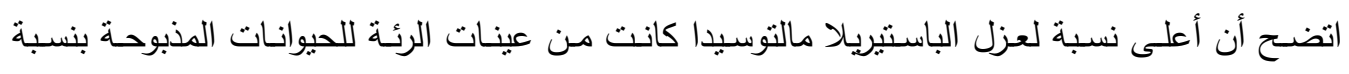
(13.1\%) ثم يليها عينات المسـات الأنفيـة بنسبة (5\%). وقد تم التاكد مـن هذه المعزولات أنها الباستيريلا مالتوسيدا مجهريا بواسطة صبغها بصبغتى الجرام والليشمان, وبيوكيميائيا بواسطة الاختبارات التقليدية وبواسطة اختبار تجارى API 20E وأيضا باستخدام تفاعل البلمرة المنسلسل ( Polymerase Chain Reaction

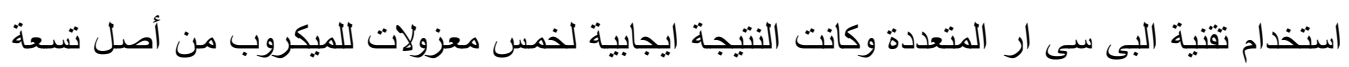
معزولات ممثلة للميكروب وأيضا نم عزل جين الكبسول E لخمس معزولات من أصل تسعة معزولات ممثلة للميكروب. وقد تم عمل اختبار البى سى ار المتعدد للمعزولات الايجابية لعزل جينات الضراوة المتمنلة في أربع جينات ضراوة (TbpA, nanH, omph and ptfA) التي نتج عنها نسب عالية (100) في عينـات الرئـة وعينـات المسـح الأفي من معزولات الأبقار والجاموس ونتج أيضا نسبة عالية لجين ptfA فى عينات الرئة بالجاموس عن عينات المسح الأنفي. 